\title{
Expression in the Placenta of Neuronal Markers for Perinatal Brain Damage
}

\author{
LIA D.E. WIJNBERGER, PETER G.J. NIKKELS, ANGELIQUE J.C.M. van DONGEN, \\ CORNELLE W. NOORLANDER, EDUARD J.H. MULDER, LOES H. SCHRAMA, $\dagger$ AND \\ GERARD H.A. VISSER \\ Departments of Obstetrics, Neonatology and Gynaecology [L.D.E.W, E.J.H.M., G.H.A.V.]; Pathology \\ [P.G.J.N.]; and Department of Medical Pharmacology, Rudolf Magnus Institute for Neurosciences \\ [A.J.C.M.v.D., C.W.N., L.H.S.], University Medical Center Utrecht, 3508 AB Utrecht, The Netherlands
}

\begin{abstract}
Determination of S-100 a and $\mathrm{b}$ and neuron-specific enolase (NSE) in (cord) blood and amniotic fluid has been used to assess neonatal neuronal damage after compromising conditions. However, these proteins are not only found in nervous tissue, and their expression in placenta and umbilical cord has never been investigated. In this study, S-100 (a and b) and NSE expression in human cord and placental tissue was studied by immunohistochemical analysis. Similar analysis was performed using two other brain-specific markers: glial fibrillary acidic protein and growth-associated protein B-50 (also known as GAP-43 or neuromodulin). Tissue was derived after elective cesarean section in seven women of different gestational ages after uncomplicated or complicated pregnancy. S-100 a and b and NSE immunoreactivity was found in several cell types and structures in the umbilical cord as well as in the placenta of all seven cases. Glial fibrillary acidic protein and B-50 showed no immunoreactivity. These data
\end{abstract}

ABSTRACT

are of importance for interpreting findings of studies in which S-100 or NSE levels in cord blood or amniotic fluid have been related to neuronal damage in the neonate. The increased levels found may just as well be caused by leakage from placenta or umbilical cord as be caused by brain damage. We conclude that S-100 a and b and NSE are not suitable markers for neonatal brain damage. Brain-restricted proteins such as glial fibrillary acidic protein and B-50 seem more promising. (Pediatr Res 51: 492-496, 2002)
GFAP, glial fibrillary acidic protein
IUGR, intrauterine growth restriction
IR, immunoreactivity
NSE, neuron-specific enolase
TBS, Tris-buffered saline

Assessment of neuronal markers in serum and cerebrospinal fluid is used in adults to detect acute and chronic brain damage (1-4). Also in perinatology, the significance of neuronal markers such as S-100 $a$ and $b$ and NSE in amniotic fluid, cord blood, neonatal blood, and neonatal cerebrospinal fluid has been investigated to predict brain damage in the newborn especially after perinatal asphyxia and preterm labor (5-13). Significantly higher values of these proteins were found under conditions associated with adverse neonatal outcome.

The S-100 family of proteins in the brain is thought to be neurotrophic in low concentrations but neurotoxic in high concentrations. The S-100a ( $\alpha \beta \mathrm{S}-100)$ isoform is present in glial cells whereas $\mathrm{S}-100 \mathrm{~b}(\beta \beta \mathrm{S}-100)$ is present in both glial and Schwann cells $(14,15)$. NSE is the $\gamma$-isoenzyme of the enolases, enzymes involved in the glycolytic pathway, and is

Received April 3, 2001; accepted November 29, 2001.

Correspondence and reprint requests: Lia Wijnberger, M.D., Department of Obstetrics, Neonatology and Gynaecology, University Medical Center Utrecht, KJ02.507.0 Wilhelmina Children's Hospital, PO Box 85090, 3508 AB Utrecht, The Netherlands; e-mail: l.wijnberger@dog.azu.nl

†Deceased. present in the cytosol of neurons $(16,17)$. The expression of S-100 a and $b$ and NSE is not restricted to the nervous system (14-17). Members of the S-100 family of proteins (e.g. S100P, S100C, S100A11) are expressed in placental tissue (18-21). However, the expression of S-100 a and b and NSE in umbilical cord and placenta tissue has never been investigated systematically. Therefore the question arises whether the IR of S-100 a and b and NSE in (cord) blood and amniotic fluid, as observed in previous studies, indicates exclusively damage in brain tissue or may also result from protein release from placental or umbilical cord tissue.

The aim of this study was to assess the IR of S-100 a and b and NSE in placental and umbilical cord tissue. The findings may help to elucidate the question of whether S-100 and NSE are specific markers in cord blood or amniotic fluid for neonatal brain damage or whether more specific nervous tissue markers have to be used. For this purpose we investigated the expression in umbilical cord and placental tissue of S-100 a and $b$ and NSE and compared this with the expression of GFAP and growth-associated protein B-50 (also designated GAP-43 
or neuromodulin) in uncomplicated and complicated pregnancies.

\section{METHODS}

Patients and tissue preparation. After the patients had given informed consent, we obtained umbilical cord and placenta tissues from seven women after elective cesarean section. Patient characteristics are shown in Table 1. Immediately after delivery, full-thickness biopsies were taken from the pericentral area of the placenta. Samples from the umbilical cord were taken at various locations. Tissue was fixed in $4 \%$ paraformaldehyde in $0.1 \mathrm{M}$ phosphate buffer, $\mathrm{pH} 7.4$ at $4^{\circ} \mathrm{C}$ overnight. The material was dehydrated in ethanol. Ethanol was removed by washing in toluene overnight at $4^{\circ} \mathrm{C}$. The material was embedded in paraffin.

Antibodies. Tissue was stained with antibodies reacting with S-100 a and b, the S-100 $\beta$-chain, NSE, GFAP, and B-50. Details of the antibodies and their dilutions are shown in Table 2.

Immunohistochemistry. Seven-micrometer paraffin sections were cut and mounted on slides coated with 3-aminopropyltriethoxysilane. First, sections were deparaffinized in ethanol. Then they were incubated for $30 \min$ in TBS $(0.01 \mathrm{M}, \mathrm{pH} 7.5$ with $\mathrm{HCl}$ ), containing $\mathrm{H}_{2} \mathrm{O}_{2}$ to inactivate the endogenous peroxidase activity. Sections were washed in TBS for $3 \times 10$ $\mathrm{min}$. Thereafter, sections were preincubated for $30 \mathrm{~min}$ at $37^{\circ} \mathrm{C}$ to block nonspecific binding in TBS containing 3\% normal goat serum when polyclonal antibody was used, and $3 \%$ nor- mal horse serum in case of an MAb. Finally, sections were incubated with the primary antibody diluted in TBS containing $1.5 \%$ normal serum at room temperature overnight.

Next day, slices were washed in TBS for $3 \times 10 \mathrm{~min}$ and then incubated with biotinylated secondary antibody, dilution 1:100 in TBS, for $1 \mathrm{~h}$. The sections were washed in TBS and incubated in avidin biotin peroxidase reagent (Vectastain ABC-kit, elite-standard, Brunschwig, Amsterdam, The Netherlands) in TBS for $1 \mathrm{~h}$ at room temperature. Sections were washed in Tris $\mathrm{HCl}(0.05 \mathrm{M}, \mathrm{pH} 7.6)$ for $3 \times 10 \mathrm{~min}$. Staining was visualized by incubation with a diaminobenzidine solution, containing $10 \mathrm{mg}$ of diaminobenzidine in $15 \mathrm{~mL}$ of Tris $\mathrm{HCl}$ with $0.024 \% \mathrm{H}_{2} \mathrm{O}_{2}$. Sections were dehydrated and coverslipped in Depex (BDH Laboratory Supplies, England). Rat brain served as a positive control and sections without primary antibody as a negative control. The brains were obtained from adult, healthy, surplus Wistar rats, and the tissue was prepared similarly as placenta and cord tissue.

\section{RESULTS}

Specificity of the neural antibodies in rat brain sections. The antibodies to S-100 a and b, the S-100 $\beta$-chain, NSE, GFAP, and B-50 showed IR in rat brain. The anti-S-100 antibodies and the anti-GFAP antibody showed positive glial cells. The anti-NSE antibody and the anti-B-50 antibody showed positive neurons. All stainings were negative when no primary antibodies were added.

Table 1. Patient characteristics

\begin{tabular}{|c|c|c|c|c|c|c|c|c|}
\hline $\begin{array}{l}\text { Gestational age } \\
\text { (weeks + days) }\end{array}$ & $\begin{array}{c}\text { Fetal } \\
\text { condition }\end{array}$ & $\begin{array}{c}\text { Maternal and } \\
\text { obstetrical pathology }\end{array}$ & $\begin{array}{l}\text { Umbilical } \\
\text { artery Doppler } \\
\text { findings }\end{array}$ & $\begin{array}{l}\text { Fetal heart } \\
\quad \text { rate } \\
\text { monitoring }\end{array}$ & $\begin{array}{l}\text { Birth weight } \\
\text { in grams } \\
\text { (percentile)* }^{*}\end{array}$ & $\begin{array}{l}\text { Apgar } \\
\text { score at } \\
5 \mathrm{~min}\end{array}$ & $\begin{array}{l}\text { Umbilical } \\
\text { artery } \mathrm{pH}\end{array}$ & Neonatal pathology \\
\hline $29+6$ & IUGR & Preeclampsia & Abnormal & Normal & $820(<2.3)$ & 9 & 7.18 & $\begin{array}{l}\text { Respiratory distress } \\
\text { syndrome, } \\
\text { bronchopulmonary } \\
\text { dysplasia, patent ductus } \\
\text { arteriosus, brain } \\
\text { ultrasound abnormalities }\end{array}$ \\
\hline $31+0$ & IUGR & None & Abnormal & Abnormal & $623(<2.3)$ & 10 & 7.09 & $\begin{array}{l}\text { Bronchopulmonary dysplasia, } \\
\text { brain ultrasound } \\
\text { abnormalities }\end{array}$ \\
\hline $39+4$ & None & Breech presentation & Normal & Normal & $3100(25-50)$ & 9 & Unknown & None \\
\hline $39+2$ & None & $\begin{array}{l}\text { Graves disease (no } \\
\text { medication, no } \\
\text { antithyroid } \\
\text { autoantibody } \\
\text { production) }\end{array}$ & Normal & Normal & $3830(90)$ & 10 & 7.31 & None \\
\hline $39+3$ & None & $\begin{array}{l}\text { Adrenogenital } \\
\text { syndrome ( } 40 \mathrm{mg} \\
\text { hydrocortisone per } \\
\text { day) }\end{array}$ & Unknown & Normal & $4120(90)$ & 10 & Unknown & None \\
\hline
\end{tabular}

* Birth weight percentiles are according to the Dutch growth charts. 
Table 2. Overview of antibodies used for immunohistochemical staining

\begin{tabular}{ccl}
\hline \multicolumn{1}{c}{ Antibody* } & Concentration & \multicolumn{1}{c}{ Supplier } \\
\hline Anti-S-100 a and b (p) & $1: 800$ & DAKO, Glostrup, Denmark \\
Anti-S-100 $\beta$ chain $(\mathrm{p})$ & $1: 400$ & Santa Cruz Biotechnology, Inc, Santa Cruz, CA, U.S.A. \\
Anti-NSE (m) & $1: 1600$ & Sanbio, Am Uden, the Netherlands \\
Anti-GFAP (p) & $1: 1600$ & Roche Molecular Biochemicals, Mannheim, Germany \\
Anti-GFAP $(\mathrm{m})$ & $1: 1600$ & Roche Molecular Biochemicals \\
Anti-B-50 (m) & $1: 200,000$ & Characterized by Mercken et al. 22 \\
Anti-B-50 (p) & $1: 100,000$ & Characterized by Aarts et al. 23 \\
\hline
\end{tabular}

* m, monoclonal; p, polyclonal.

S-100 staining. Immunohistochemical analysis of both the anti-S-100 a and b and the anti-S-100 $\beta$-chain antibodies showed IR in the umbilical cord, owing to positive staining of the smooth muscle cells of the vascular wall, myofibroblasts in Wharton's jelly, amnion epithelium, macrophages, and monocytes (Fig. 1, $A$ and $B$ ). In the placenta the anti-S100 antibodies showed IR of the syncytiotrophoblast, myofibroblasts, smooth muscle cells of the vascular wall, and macrophages (Fig. $2 A$ ).

NSE staining. In the umbilical cord the NSE antibody showed IR of the smooth muscle cells of the vascular wall, endothelium, myofibroblasts in Wharton's jelly, amnion epithelium, macrophages, and monocytes (Fig. 1C). In the placenta the NSE antibody stained the syncytiotrophoblast, myo- fibroblasts, macrophages, smooth muscle cells of the vascular wall, and the endothelium (Fig. 2B).

GFAP and B-50 staining. The GFAP and the B-50 antibodies showed no IR in umbilical cord or placenta. A summary of the results of the immunohistochemical staining is given in Table 3. The results were the same in tissues obtained from all pregnancies.

\section{DISCUSSION}

We demonstrated IR for the S-100 protein ( $\mathrm{a}$ and $\mathrm{b}$ and the S-100 $\beta$-chain) and NSE in several cell types and structures of umbilical cord and placental tissue. In contrast to these find-
$1 \mathrm{~A}$
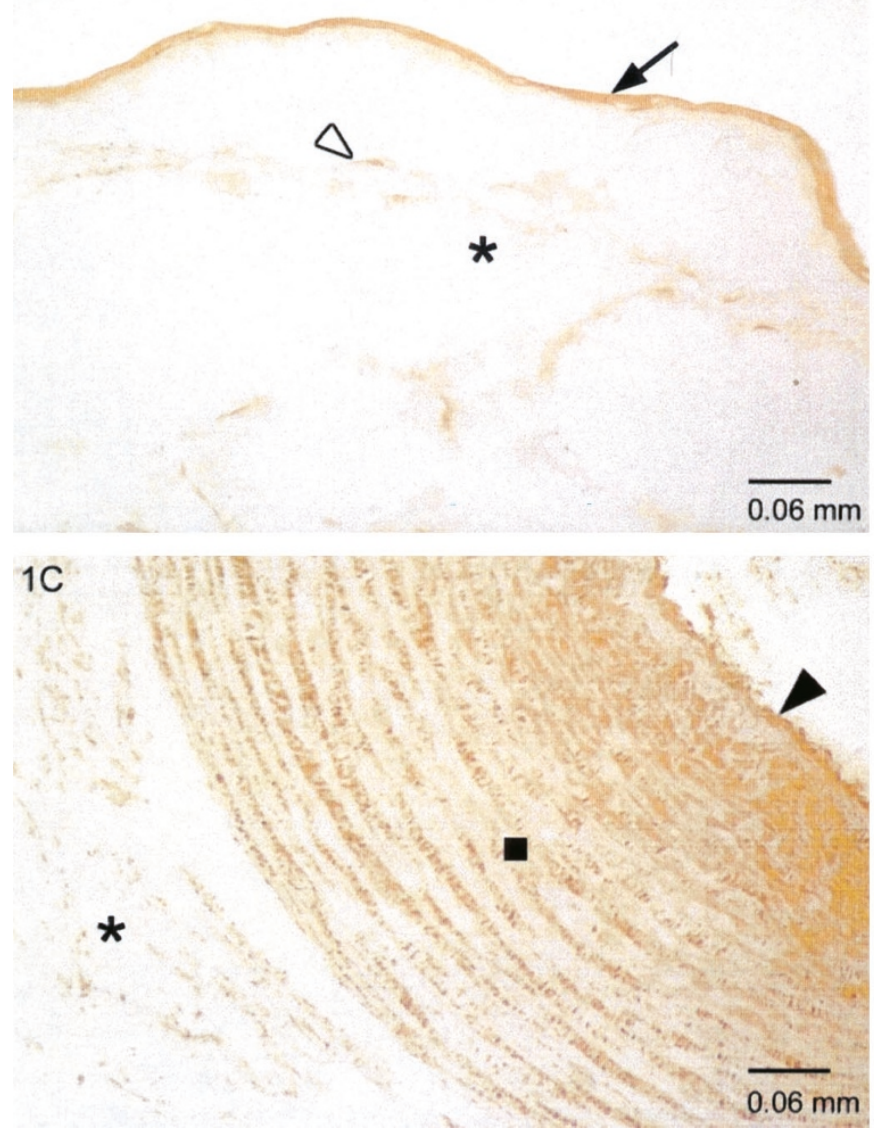

$1 \mathrm{~B}$

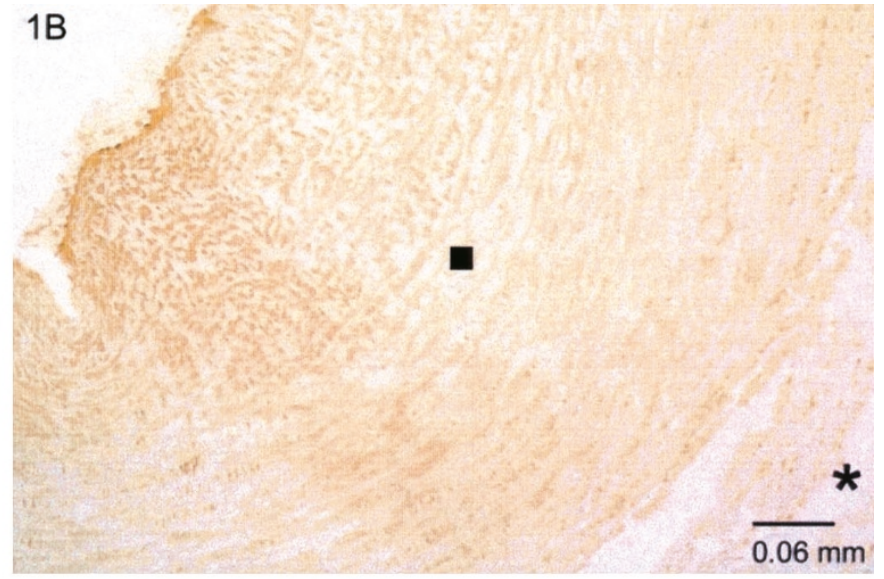

Figure 1. Expression of markers in umbilical cord tissue. Expression of the S-100 a and b antibody in myofibroblasts in Wharton's jelly and amnion epithelium $(A)$ and in smooth muscle cells of the vascular wall $(B)$. The S-100 $\beta$-chain antibody showed the same IR. $C$, NSE IR in the smooth muscle cells of the vascular wall and endothelium of an artery. The myofibroblasts in the Wharton's jelly also showed NSE IR. *, Wharton's jelly; $\triangleright$, myofibroblast; $\rightarrow$, amnion epithelium;

$\bullet$, endothelium; $\mathbf{\square}$, vascular wall. 

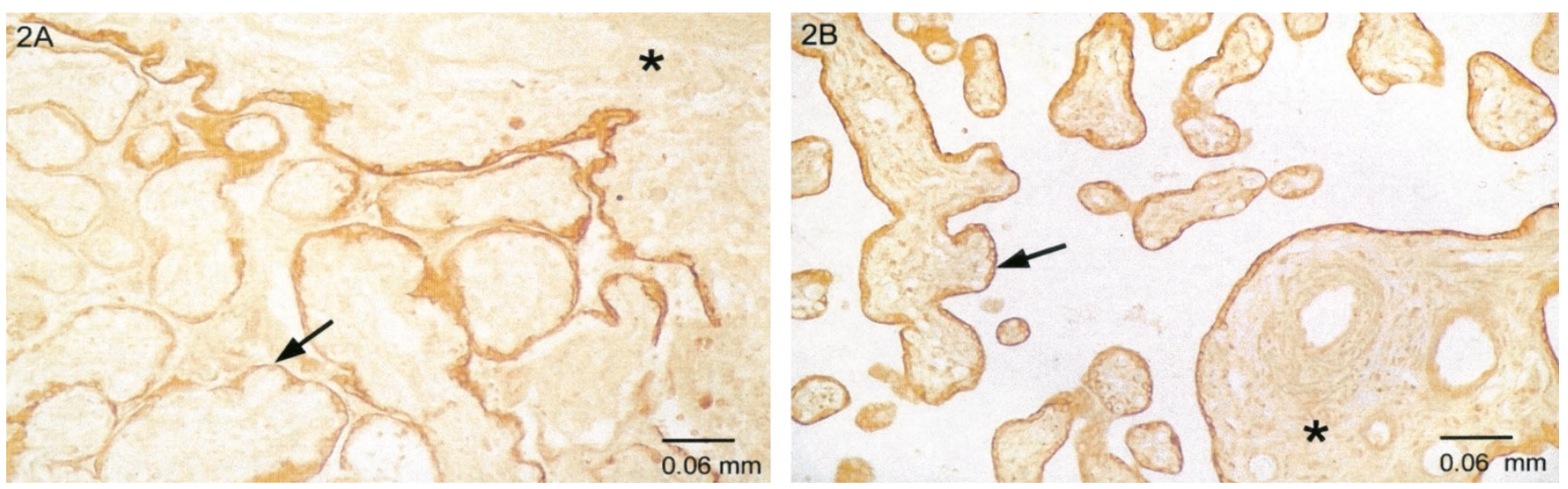

Figure 2. Expression of neuronal markers in placenta tissue. $A, \mathrm{~S}-100$ expression in syncytiotrophoblast, myofibroblasts in stroma, and macrophages. $B$, NSE IR of syncytiotrophoblast and myofibroblasts in stroma. *, stem villi; $\rightarrow$, trophoblast.

Table 3. Overview of results of staining with S-100, NSE, GFAP, and B-50

\begin{tabular}{|c|c|c|c|c|}
\hline Antibody* & \multicolumn{2}{|r|}{ Umbilical cord staining } & \multicolumn{2}{|r|}{ Placenta staining } \\
\hline S-100 a and b & + & $\begin{array}{l}\text { smooth muscle cells of the vascular wall, } \\
\text { myofibroblasts, amnion epithelium, } \\
\text { macrophages, and monocytes }\end{array}$ & + & $\begin{array}{l}\text { syncytiotrophoblast, myofibroblasts, smooth } \\
\text { muscle cells of the vascular wall, and } \\
\text { macrophages }\end{array}$ \\
\hline S-100 $\beta$ chain & + & $\begin{array}{l}\text { smooth muscle cells of the vascular wall, } \\
\text { myofibroblasts, amnion epithelium, } \\
\text { macrophages, and monocytes }\end{array}$ & + & $\begin{array}{l}\text { syncytiotrophoblast, myofibroblasts, smooth } \\
\text { muscle cells of the vascular wall, and } \\
\text { macrophages }\end{array}$ \\
\hline GFAP (p)/GFAP (m) & - & & - & \\
\hline B-50 (m)/B-50 (p) & - & & - & \\
\hline
\end{tabular}

* m, monoclonal; p, polyclonal.

ings, no IR of the glial-specific marker GFAP or the neuronalspecific marker B-50 could be found in any of the investigated tissues. The results were consistently found in the tissues obtained from the three IUGR and the four uncomplicated pregnancies.

Levels of NSE and S-100 have been determined quantitatively in cord blood after normal pregnancies to obtain reference values $(24,25)$ or to relate levels to gestational age in term and preterm pregnancies (26). To have an indication of brain damage after adverse perinatal conditions, the presence of neuronal-specific proteins in blood and amniotic fluid has been investigated. In amniotic fluid, increased NSE levels have been found in pregnancies with subsequent adverse neonatal neurologic outcome $(5,11)$. Di Iorio et al. (12) determined S-100 in cord blood from IUGR fetuses. They found lower $\mathrm{S}-100$ values when nitric oxide was given to the mother to increase uteroplacental circulation. The authors suggested that IUGR fetuses may have neuronal cell injury.

The presence of S-100 a and b and the S-100 $\beta$-chain and NSE IR in several structures and cells of cord and placenta tissue questions the validity of these proteins as neuronal markers in cord blood. Increased leakage from a damaged placenta caused by villitis or infarction may explain elevated (cord) blood and amniotic fluid S-100 and NSE levels, and a relation with adverse neurologic outcome may be indirect rather than direct. The presence of S-100 a and b and NSE in cord and placental tissue has to our knowledge not been studied before. However, not only the presence of the proteins in placental and cord tissue has to be taken into consideration. Brown et al. (2) found relatively high levels of NSE in erythrocytes. They concluded that NSE is not a useful marker in blood unless hemolysis of erythrocytes is adequately assessed. Elimian et al. (11) suggested the development of an assay to distinguish between NSE released from erythrocytes containing one $\gamma$ subunit and NSE measured after neuronal damage, which contains the $\gamma \gamma$ isoenzyme. Moreover, S- 100 has a short biologic half-life, $25-40 \mathrm{~min}$ according to a recent publication and approximately $2 \mathrm{~h}$ according to other investigators $(27,28)$. This makes assessment of brain damage by means of S-100 determination only valuable after acute situations or in conditions with a continuous protein release from the brain.

Because of these arguments and the results of our findings, our opinion is that there may be a relation between damage in the nervous system and elevated NSE and S-100 in, for example, (cord) blood, but this relation might not be causal.

The direct assessment of neurologically adverse effects in the newborn by means of markers in peripheral blood is of great clinical significance. First, knowledge of neurologic damage could be helpful after a serious compromising event to decide whether to start treatment and to determine which treatment should be started. Next, serial measurements of 
brain-specific proteins can be used to monitor effects of pharmacologic interventions to protect the brain. Third, determination of brain-specific markers may be valuable in the evaluation of possibly adverse or beneficial effects of new interventions. According to our results, S-100 a and b and NSE seem to be not specific enough to serve as markers of brain damage in cord blood or amniotic fluid. Serial measurements of NSE and S-100 in one neonate, which means measurement in cord blood and sequential measurements after birth in neonatal blood, might help to distinguish between protein released from placental and umbilical cord tissue or from tissue of neonatal origin. However, even when one could distinguish between placental or cord origin and neonatal origin, the question remains whether S-100 or NSE from the neonate is coming from nervous tissue $(14-17,29)$.

We also studied the expression of GFAP and B-50. GFAP is a filament protein expressed in the cytoplasm of astrocytes (7). B-50 is a growth-associated presynaptic protein, expressed in neurons (30). Although B-50 is mainly attached to the membrane in the adult situation, during development approximately $50 \%$ of the protein is present in the cytoplasm. GFAP and B-50 seem promising as markers for neuronal damage in the neonate inasmuch as no IR of these proteins was found in placenta or umbilical cord.

\section{REFERENCES}

1. Persson L, Hårdemark HG, Gustafsson J, Rundström G, Mendel-Hartvig I, Esscher T, Påhlman S 1987 S-100 protein and neuron-specific enolase in cerebrospinal fluid and serum: markers of cell damage in human central nervous system. Stroke 18:911-918

2. Brown KW, Kynoch PA, Thompson RJ 1980 Immunoreactive nervous system of specific enolase (14-3-2 protein) in human serum and cerebrospinal fluid. Clin Chim Acta 101:257-264

3. Aurell A, Rosengren LE, Karlsson B, Olsson JE, Zbornikova V, Haglid KG 1991 Determination of S-100 and glial fibrillary acidic protein concentrations in cerebrospinal fluid after brain infarction. Stroke 22:1254-1258

4. Westaby S, Johnsson P, Parry AJ, Blomqvist S, Solem JO, Alling C, Pillai R, Taggart DP, Grebenik C, Stahl E 1996 Serum S100 protein: a potential marker for cerebral events during cardiopulmonary bypass. Ann Thorac Surg 61:88-192

5. Zinsmeyer J, Marangos PJ, Issel EP, Gross J 1987 Neuron specific enolase in amniotic fluid - a possible indicator for fetal distress and brain implication. J Perinat Med 15:199-202

6. Garcia-Alix A, Cabaòas F, Pellicer A, Hernanz A, Stiris TA, Quero J 1994 Neuronspecific enolase and myelin basic protein: relationship of cerebrospinal fluid concentrations to the neurologic condition of asphyxiated full-term infants. Pediatrics 93:234-240

7. Blennow M, Hagberg H, Rosengren L 1995 Glial fibrillary acidic protein in the cerebrospinal fluid: a possible indicator of prognosis in full-term asphyxiated newborn infants? Pediatr Res 37:260-264
8. Kothari JM, Sheftal D, Puppala B, Okrent D, Angst D 1995 Serum neuron specific enolase in preterm infants at risk of intraventricular hemorrhage. Pediatr Res 37(suppl):218A(abstr)

9. Thornberg E, Thiringer K, Hagberg H, Kjellmer I 1995 Neuron specific enolase in asphyxiated newborns: association with encephalopathy and cerebral function monitor trace. Arch Dis Child Fetal Neonatal Ed 72:F39-F42

10. Blennow M, Rosengren L, Jonsson S, Forssberg H, Katz-Salamon M, Hagberg H, Hesser U, Lagercrantz H 1996 Glial fibrillary acidic protein is increased in the cerebrospinal fluid of preterm infants with abnormal neurological findings. Acta Paediatr 85:485-489

11. Elimian A, Figueroa R, Verma U, Visintainer P, Sehgal PB, Tejani N 1998 Amniotic fluid neuron-specific enolase: a role in predicting neonatal neurologic injury? Obstet Gynecol 92:546-550

12. Di Iorio R, Marinoni E, Gazzolo D, Villacio B, Corrado G, Michetti F, Cosmi EV 1999 Maternal nitric oxide administration reduces plasma S-100 protein concentration in IUGR fetuses. J Soc Gynecol Invest 6(suppl):182A(abstr)

13. Gazzolo D, Vinesi P, Bartocci M, Geloso MC, Bonacci W, Serra G, Haglid KG, Michetti F 1999 Elevated S-100 blood level as an early indicator of intraventricular hemorrhage in preterm infants: correlation with cerebral Doppler velocimetry. J Neurol Sci 170:32-35

14. Fanò G, Biocca S, Fulle S, Mariggio MA, Belia S, Calissano P 1995 The S-100: a protein family in search of a function. Prog Neurobiol 46:71-82

15. Zimmer DB, Cornwall EH, Landar A, Song W 1995 The S100 protein family: history, function, and expression. Brain Res Bull 37:417-429

16. Kaiser E, Kuzmits R, Pregant P, Burghuber O, Worofka W 1989 Clinical biochemistry of neuron specific enolase. Clin Chim Acta 183:13-31

17. Royds JA, Taylor CB, Timperley WR 1985 Enolase isoenzymes as diagnostic markers. Neuropathol Appl Neurobiol 11:1-16

18. Becker T, Gerke V, Kube E, Weber K 1992 S100P, a novel $\mathrm{Ca}^{2+}$-binding protein from human placenta. cDNA cloning, recombinant protein expression and $\mathrm{Ca}^{2+}$ binding properties. Eur J Biochem 207:541-547

19. Mailliard WS, Haigler HT, Schlaepfer DD 1996 Calcium-dependent binding of S100C to the N-terminal domain of annexin I. J Biol Chem 271:719-725

20. Inada H, Naka M, Tanaka T, Davey GE, Heizmann CW 1999 Human S100A11 exhibits differential steady-state RNA levels in various tissues and a distinct subcellular localization. Biochem Biophys Res Commun 263:135-138

21. Emoto Y, Kobayashi R, Akatsuka H, Hidaka H 1992 Purification and characterization of a new member of the S-100 protein family from human placenta. Biochem Biophys Res Commun 182:1246-1253

22. Mercken M, Lubke U, Vandermeeren M, Gheuens J, Oestreicher AB 1992 Immunocytochemical detection of the growth-associated protein B-50 by newly characterized monoclonal antibodies in human brain and muscle. J Neurobiol 23:309-321

23. Aarts LH, Schotman P, Verhaagen J, Schrama LH, Gispen WH 1998 The role of the neural growth associated protein B-50/GAP-43 in morphogenesis. Adv Exp Med Biol 116:85-106

24. Kintzel K, Sonntag J, Strauss E, Obladen M 1998 Neuron-specific enolase: reference values in cord blood. Clin Chem Lab Med 36:245-247

25. Amer-Wahlin I, Herbst A, Lindoff C, Thorngren-Jerneck K, Marsal K, Alling C 2001 Brain-specific NSE, and S-100 proteins in umbilical blood after normal delivery. Clin Chim Acta 304:57-63

26. Gazzolo D, Bruschettini M, Corvino V, Oliva R, Sarli R, Lituania M, Bruschettini P, Michetti F $2001 \mathrm{~S} 100 \mathrm{~b}$ protein concentrations in amniotic fluid correlate with gestational age and with cerebral ultrasound scanning results in healthy fetuses. Clin Chem 47:954-956

27. Jonsson H, Johnsson P, Hoglund P, Alling C, Blomquist S 2000 Elimination of S100B and renal function after cardiac surgery. J Cardiothorac Vasc Anesth 14:698-701

28. Usui A, Kato K, Abe T, Murase M, Tanaka M, Takeuchi E 1989 S-100ao protein in blood and urine during open-heart surgery. Clin Chem 35:1942-1944

29. Johnsson P 2000 S100-B in blood: a marker of brain damage or simply a covariate? Scand Cardiovasc J 34:548-549

30. Oestreicher AB, de Graan PNE, Gispen WH, Verhaagen J, Schrama LH 1997 B-50, the growth associated protein of cell morphology and communication in the nervous system. Progr Neurobiol 53:627-686 